\title{
Prognostic Factor of Soluble ST2 Serum on 90 Days-Major Cardiovascular Events in ST-Elevation Acute Myocardial Infarction Patients with Reperfusion Therapy
}

\author{
Pamrayogi Hutomo ${ }^{1 *}$, Anggoro Budi Hartopo ${ }^{1}$, Indah Sukmasari ${ }^{2}$, \\ Ira Puspitawati², Putrika Prastuti Ratna Gharini' ${ }^{1}$, Budi Yuli Setianto ${ }^{1}$
}

1. Department of Cardiology and Vascular Medicine Faculty of Medicine Universitas Gadjah Mada - Dr. Sardjito Hospital, Yogyakarta, Indonesia

2. Department of Clinical Pathology Faculty of Medicine Universitas Gadjah Mada - Dr. Sardjito Hospital, Yogyakarta, Indonesia

${ }^{*}$ Corresponding author:

Pamrayogi Hutomo, MD, - email: pamrayogihutomo@gmail.com

Department of Cardiology and Vascular Medicine Faculty of Medicine Universitas Gadjah Mada - Dr. Sardjito Hospital, Jalan Farmako Sekip Utara Yogyakarta, 55281, Indonesia,.

Manuscript submitted: June 12, 2017; Revised and accepted for publication: July 24, 2017

\section{ABSTRACT}

Background: Soluble ST2 (sST2) is released by strained myocardial. High baseline sST2 levels have been shown to be a predictor of mortality and heart failure in STEMI patients within 30 days and within 1 year, but its effect on medium-term events has not been widely investigated. Aims: To assess the prognostic factor of sST2 levels during admission with major cardiovascular events in the form of cardiovascular death and heart failure due to left ventricular dysfunction within 90 days of observation.

Methods: A retrospective cohort study was conducted on STEMI patients with an onset of $\leq$ 24 hours undergoing reperfusion therapy from April 2014 - June 2015 in Dr. Sardjito General Hospital, Yogyakarta, Indonesia. The SST2 sample of venous blood was performed at admission. Primary outcomes for this analysis included cardiovascular death and congestive heart failure (CHF) through 90 days of follow-up. Assessment of major cardiovascular events was based on medical record data. Bivariate analysis were conducted on demographic and clinical factors related to SST2 and major cardiovascular events. A multivariate analysis was then conducted to determine the independent factors that influenced the emergence of major cardiovascular events. Results: Of the 107 patients who met the subject criteria, there were $33(30.8 \%)$ subjects with major cardiovascular events and 74 subjects $(69.2 \%)$ without major cardiovascular events in 90 days of observation. Of the 33 subjects with major cardiovascular events, there were 10 subjects $(9.3 \%)$ died and 23 subjects $(21.5 \%)$ with heart failure. The SST2 levels did not have a significant relationship with the incidence of mortality $(p=0.617)$, heart failure $(p=1.000)$, or both combined $(p=1.000)$ in 90 days of observation.

Conclusion: High serum sST2 levels during admission in STEMI patients who had undergone reperfusion therapy were not associated with increased incidence of major cardiovascular events (either the incidence of mortality or heart failure alone or both combined) in 90 days observation.

Keywords: STEMI; soluble ST2; major cardiovascular events; mortality; heart failure

\section{INTISARI}

Latar Belakang: Biomarka SST2 dilepaskan oleh miokard yang mengalami regangan. Kadar SST2 fase awal yang tinggi telah terbukti sebagai predictor mortalitas dan gagal jantung pada pasien IMA-EST dalam 30 hari dan dalam 1 tahun, namun pengaruhnya terhadap kejadian jangka menengah belum banyak diteliti. Studi ini bertujuan untuk menilai faktor prognostic kadar sST2 saat admisi dengan kejadian kardiovaskular mayor (KKM) berupa kematian dan gagal jantung akibat disfungsi ventrikel kiri dalam 90 hari pengamatan.

Metode Penelitian: Penelitian kohort retrospektif dilakukan terhadap pasien IMA-EST dengan awitan $\leq 24$ jam yang menjalani terapi reperfusi mulai April 2014-Juni 2015. Sampel sST2 dari darah vena dilakukan pada saat admisi. Pasien dinilai munculnya KKM dalam 90 hari pasca 
IMA-EST berdasarkan data rekam medis. Analisis bivariate dilakukan terhadap faktor demografi dan klinis yang berhubungan dengan SST2 dan KKM. Analisis multi variate lalu dilakukan untuk mengetahui faktor independen yang mempengaruhi munculnya KKM.

Hasil: Dari 107 pasien yang memenuhi kriteria subjek penelitian, terdapat $33(30,8 \%)$ subjek dengan KKM dan 74 subjek $(69,2 \%)$ tanpa KKM selama 90 hari pengamatan. Dari 33 subjek dengan KKM, terdapat 10 subjek $(9,3 \%)$ meninggal dan 23 subjek $(21,5 \%)$ dengan gagal jantung. Kadar SST2 tidak memiliki hubungan yang signifikan dengan mortalitas $(p=0,617)$, kejadian gagal jantung $(p=1,000)$, maupun gabungan keduanya $(p=1,000)$ dalam 90 hari.

Simpulan: Kadar SST2 serum yang tinggi saat admisi pada pasien IMA-EST yang telah menjalani terapi reperfusi tidak berhubungan dengan meningkatnya insidensi KKM (baik mortalitas atau kejadian gagal jantung saja maupun gabungan keduanya) selama 90 hari pengamatan pasca IMA-EST.

\section{INTRODUCTION}

In the United States, data from 20052008, showed that in ST elevation myocardial infarction (STEMI) patient age $\geq 65$ years, the median value of a 30-day mortality rate from acute myocardial infarction was $16.6 \%$ while readmission rate was $19.9 \%$ for acute myocardial infarction and $24.4 \%$ for heart failure. ${ }^{1}$ Since the introduction of reperfusion therapy, percutaneous coronary intervention ( $\mathrm{PCl}$ ), antithrombotic therapy and secondary prevention treatment to date can reduce major adverse cardiovascular events (MACE) in hospitals by $50 \%$. The hospital mortality rate also decreased from $7.2-12.5 \%{ }^{2}$ The mortality rate in 1 year ranged from $7-18 \%{ }^{3}$ Nevertheless, mortality rates and MACE still persisted at level of $12 \%$ which persisted up to 6 months post-infarction observation in patients at high risk. ${ }^{4}$ Furthermore, the incidence of heart failure after myocardial infarction is about $20 \% .^{5}$ Approximately $40 \%$ of myocardial infarction is followed by left ventricular systolic dysfunction. ${ }^{5}$ The above facts indicate that the incidence of heart failure after myocardial infarction is a frequent occurrence.

Soluble ST2 (SST2) as one of the newly investigated biomarkers may be more specific in heart disease because it is released from stretched cardiomyocytes. Increased SST2 levels in patients with myocardial infarction are associated with an increased risk of mortality and heart failure.
In contrast to NT-proBNP, sST2 levels are not affected by age, previous heart failure status, atrial fibrillation, body mass index, or renal function obtained from studies involving the general and high risk population. ${ }^{6}$

Several large studies have concluded the role of high initial phase sST2 levels on MACE in STEMI patients within 30 days, 1 and 3,5 years. ${ }^{7,8}$ But few studies have examined the effect of SST2 on mid-term MACE events in STEMI patients. Further studies need to be done to strengthen evidence of the role of SST2 in influencing the clinical course and the occurrence of heart failure in STEMI especially in the medium term. This study aims to investigate the role of high levels of sST2 measured at admission to the occurrence of MACE within 90 days in STEMI patients with reperfusion.

\section{METHODS}

This is a retrospective cohort study which is was part of previous study. ${ }^{9}$ In this current study, we continued to observe the occurrence of MACE of heart failure due to left ventricular dysfunction within 90 days after STEMI to see if baseline SST2 levels were associated with the occurrence of MACE (heart failure, readmission due to heart failure, cardiovascular mortality) in medium term.

The initial sampling of the research subjects was conducted in Emergency Room and Intensive Cardiac Care Unit (ICCU) Dr. 
Sardjito General Hospital Yogyakarta, Indonesia from April 2014 until June 2015. ${ }^{9}$

The observations of the research subjects were carried out from the time of hospital treatment at ICCU Dr. Sardjito General Hospital, up to 90 days since the onset of STEMI attack where the data obtained from the results of medical record in Medical Record Installation of Dr. Sardjito General Hospital Yogyakarta or by phone if medical record data was not completely available.

The STEMI patients, age 30-75 years, with an onset $\leq 24$ hours admitted via the Emergency Department of Dr. Sardjito General Hospital, Yogyakarta and undergoing reperfusion therapy with fibrinolysis or primary $\mathrm{PCl}$ on sitewere consecutively sampled andselected as research subjects. Exclusion criteria were a history of chronic renal failure stage IV, history of chronic heart failure before attack, hepatic cirrhosis, patients with pneumonia and/or chronic obstructive pulmonary disease acute exacerbations during hospitalization, patients with sepsis during hospitalization, patients with Killip class $>$ II at admission, malignancy, patients who have undergone pre-admission fibrinolysis, patients with fibrinolysis failure, and incomplete medical records data where patients can not be contacted.

Demographic data (gender, age, smoking status, history of diabetes mellitus, hypertension, and chronic accompanying diseases such as chronic kidney disease, chronic heart failure, hepatic cirrhosis, chronic obstructive pulmonary disease and malignancy), clinical profile (systolic and diastolic blood pressure, heart rate and Killip class), electro cardiogram, and laboratory features were collected and recorded in the case report form. An electro cardiogram (ECG) image is made with a 12-leads ECG. The right precordial leads (V2R, V3R and V4R) and posterior leads (V7, V8 and $\mathrm{V} 9$ ) are performed where necessary.
The ECG was assessed during admission and during hospitalization. Routine laboratory data include (1) hemoglobin, leukocyte count, platelet count, (2) creatinine (3) blood glucose at admission and (4) cardiac enzyme (creatine kinase (CK), CK-MB and troponin I).

Blood sampling and laboratory tests were performed during admission at the Emergency Room and 24 hours post-admission at ICCU Dr. Sardjito General Hospital and sent to the Clinical Pathology Laboratory Dr. Sardjito General Hospital for immediate routine checks. The admission blood sample was then treated for serum isolation. ${ }^{9}$

The sST2 is a glycoprotein and a family of the interleukin-1 receptor. SST2 is an isoform with a molecular weight of 60 kilo Dalton generated from alternate splicing of a transmembrane form with a molecular weight of $120 \mathrm{kDa} .{ }^{10}$ Samples for SST2 were taken from venous blood at the time of admission at the Dr. Sardjito General Hospital, stored in aliquot form on a micro tube and refrigerated at $-80^{\circ} \mathrm{C}$ until analysis is performed. The SST2 levels were detected and measured by ELISA sandwich method with an R\&D system kit. $^{9}$

Reperfusion therapy includes fibrinolysis or primary $\mathrm{PCl}$ according to hospital procedures. Decisions on choice of reperfusion therapy were not influenced by this study. The subjects were then treated intensively at ICCU until stabilized for subsequent transfer to the ward or discharged.

During the 90 days since the onset of STEMI, based on medical record data, subjects were assessed against the occurence of MACE (heart failure, read mission due to heart failure, and cardiovascular death within 90 days of observation since the onset of STEMI. Death was mortality due to cardiovascular causes occurring within 90 days of observation since STEMI event by cardiovascular cause. Heart failureis defined as confirmed diagnosis of heart 
failure, the administration of diuretic drugs, and the presence of signs and symptoms in medical record data. Heart failure readmission was defined as hospital care where heart failure was the main reason for hospitalization and requires management with diuretics, inotropes, or nitrates. The management of the subject at the time of treatment was performed solely by the physician in charge of the patient and was not influenced by this study. MACE were obtained from medical records and telephone confirmations of patients and families. Assessment was not influenced by the research and the assessor does not know the results of SST2 concentration on the subject.

Subjects were divided into two groups: groups with high serum SST2 (supramedian) and low serum SST2 group (inframedian). Baseline characteristics between the two groups was analyzed by chi-square test (for categorical data), Independent Sample T test (numerical data with normal distribution) and Mann-Whitney test (numerical data with abnormal distribution). The proportion of MACE within 90 days after STEMI between two groups was analysedby chi-square test. Multivariate analysis with confounding variables $(p<0.25)$ that play a role in the occurance of MACE was done with logistic regression analysis, if necessary. The $p$ value $<0.05$ was defined as the statistical significance limit. The analysis was performed with SPSS version 20.

This research has obtained ethical clearance approval from the Ethics Commission of Faculty of Medicine UGM and Dr. Sardjito General Hospital with reference number: No Ref: KE/FK/494/EC/2016.

\section{RESULT}

A total of 107 subjects were analyzed in this study. The median level of sST2 in this study subjects was $751.16 \mathrm{pg} / \mathrm{mL}$. Minimum level obtained is $257.99 \mathrm{pg} / \mathrm{mL}$, while the maximum level is $1029 \mathrm{pg} / \mathrm{mL}$. The 25 and $75^{\text {th }}$ percentile values are $696.38 \mathrm{pg} / \mathrm{mL}$ and $824.81 \mathrm{pg} / \mathrm{mL}$ respectively. The result of data normality test by Klomogorov-Smirnov test showed that the SST2 content was not normally distributed $(p<0.05)$. This research uses cut off value of SST2 based on median $(751.16 \mathrm{pg} / \mathrm{mL})$.

The subjects were divided into two groups based on these values, ie group with SST2 $\leq$ $751.16 \mathrm{pg} / \mathrm{mL}$ and group with SST2> 751.16 $\mathrm{pg} / \mathrm{mL}$. Statistically, there were no significant differences in characteristics between the two groups. The basic characteristics of research subjects in STEMI patients are shown in Table 1.

There were $33(30.8 \%)$ subjects experiencing MACE and 74 subjects $(69.2 \%)$ who did not experience MACE for 90 days of observation. Of 33 subjects with MACE, there were 10 subjects $(9.3 \%)$ died and 23 subjects $(21.5 \%)$ with heart failure. Significantly different variables in both groups were based on combined MACE (mortality and incidence of heart failure), among others: age $(p=0.012)$, blood glucose level $(p=0.018)$, creatine kinase $(p=0.010)$, creatine kinase-MB $(p=0.004)$, and troponin I $(p<0.001)$. The other variables did not differ significantly between the two groups (Table 2).

We compared the basic characteristics between the group experiencing death and those who did not. Significantly different variables in both groups based on mortality in this study were age variables $(p=0.032)$ and onset of infarction $(p=0.018)$. The other variables did not differ significantly between the two groups (Table 3 ).

When compared to the basic characteristics between groups experiencing heart failure and those who do not, there were significantly different variables in both groups in this study of active smokers $(p=0.047)$, anterior STEMI location $(p=0.042)$, blood glucose level $(p=$ $0.038)$, creatine kinase $(p=0.001)$, creatine kinase-MB ( $p=0.002)$, and troponin I $(p<0.001)$. The other variables did not differ significantly between the two groups (Table 4). 
Table 1.Comparison of baseline characteristics of group with high sST2 (>751.16 pg/mL) and low $(\leq$ $751.16 \mathrm{pg} / \mathrm{mL}$ ) levels in STEMI with reperfusion

\begin{tabular}{|c|c|c|c|}
\hline Characteristic & $\begin{array}{c}\text { High sST2 } \\
\quad(n=54)\end{array}$ & $\begin{array}{l}\text { Low sST2 } \\
\qquad(n=53)\end{array}$ & $p$ value \\
\hline Sex, n (\%) & & & 0.429 \\
\hline Male & $46(85.2)$ & $41(77.4)$ & \\
\hline Female & $8(14.8)$ & $12(22.6)$ & \\
\hline Age (year) & $57.2 \pm 9.4$ & $56.9 \pm 8.5$ & 0.898 \\
\hline Diabetes mellitus, $\mathrm{n}(\%)$ & $11(20.4)$ & $15(28.3)$ & 0.465 \\
\hline Hypertension, n (\%) & $33(61.1)$ & $32(60.4)$ & 1.000 \\
\hline Active smoker, n (\%) & $32(59.3)$ & $30(56.6)$ & 0.934 \\
\hline Onset (hour) ${ }^{* *}$ & $5(2-24)$ & $5(2-24)$ & 0.975 \\
\hline Systolic blood pressure $(\mathrm{mmHg})^{* *}$ & $137.5(80-190)$ & $130(80-200)$ & 0.225 \\
\hline Diastolic blood pressure $(\mathrm{mmHg})^{* *}$ & $80.5(44-110)$ & $80.0(50-140)$ & 0.475 \\
\hline Anterior STEMI, n (\%) & $28(51.9)$ & $24(45.3)$ & 0.627 \\
\hline Haemoglobin $(\mathrm{g} / \mathrm{dL})^{*}$ & $14.05 \pm 1.9$ & $14.07 \pm 1.9$ & 0.954 \\
\hline White Blood Cell $\left(10^{3} / \mu \mathrm{L}\right)^{*}$ & $13.4 \pm 4.1$ & $14.05 \pm 3.92$ & 0.382 \\
\hline Platelet $\left(10^{3} / \mu \mathrm{L}\right)^{* *}$ & $242(144-704)$ & $268(117-655)$ & 0.106 \\
\hline Creatinine $(\mathrm{mg} / \mathrm{dL})$ * & $1.16 \pm 0.29$ & $1.18 \pm 0.30$ & 0.864 \\
\hline Blood Glucose $(\mathrm{g} / \mathrm{dL})^{* *}$ & $146.5(89-566)$ & $150(86-521)$ & 0.871 \\
\hline GOT $(\mathrm{IU} / \mathrm{L})^{* *}$ & $44.5(13-263)$ & $44.0(12-497)$ & 0.911 \\
\hline Creatine kinase $(\mathrm{IU} / \mathrm{mL})^{* *}$ & $681.5(40-7404)$ & $1053(39-5884)$ & 0.815 \\
\hline Creatine kinase $-\mathrm{MB}(\mathrm{IU} / \mathrm{mL})^{* *}$ & $77.5(20-975)$ & $95(14-652)$ & 0.786 \\
\hline Troponin I $(\mathrm{ng} / \mathrm{mL}) * *$ & $1.35(0.01-44)$ & $2.04(0.01-30)$ & 0.452 \\
\hline Reperfusion method, n (\%) & & & 0.203 \\
\hline Primary $\mathrm{PCl}$ & $28(51.9)$ & $20(37.7)$ & \\
\hline Fibrinolysis & $26(48.1)$ & $33(62.3)$ & \\
\hline Heparin, n (\%) & $50(92.6)$ & $53(100.0)$ & 0.061 \\
\hline ACEi/ARB, n (\%) & $49(90.7)$ & $49(92.5)$ & 0.512 \\
\hline Beta blocker, n (\%) & $49(90.7)$ & $46(86.8)$ & 0.733 \\
\hline CCB, n (\%) & $11(20.4)$ & $7(13.2)$ & 0.464 \\
\hline Combined MACE, n (\%) & $16(29.6)$ & $17(32.1)$ & 0.949 \\
\hline Death, n (\%) & $5(9.3)$ & $5(9.4)$ & 0.617 \\
\hline Heart Failure, n (\%) & $11(20.4)$ & $12(22.6)$ & 0.960 \\
\hline
\end{tabular}

MACE: major advance cardiovascular event, STEMI: ST-elevation myocardial infarction, GOT: glutamic oxaloacetate transaminase, PCl: percutaneous coronary intervention, ACEi: angiotensin converting enzyme inhibitor, ARB: angiotensin receptor blocker. CCB: calcium channel blocker.

*normal data distribution, presented as mean and standart deviation, analysed with unpaired T-test

**abnormal data distribution, presented as median (minimum-maximum), analysed with Mann-Whitney test. 
Table 2. Comparison of baseline characteristics based on a combined MACE event for 90 days in STEMI patients with reperfusion

\begin{tabular}{|c|c|c|c|}
\hline Characteristic & $\begin{array}{c}\text { MACE }(+) \\
(n=33)\end{array}$ & $\begin{array}{c}\text { MACE }(-) \\
(\mathrm{n}=74)\end{array}$ & $P$ value \\
\hline$\overline{S e x, n(\%)}$ & & & 0.152 \\
\hline Male & $30(90.9)$ & $57(77)$ & \\
\hline Female & $3(9.1)$ & $17(23)$ & \\
\hline Age $(\text { year })^{*}$ & $60.3 \pm 9.3$ & $55.6 \pm 8.4$ & 0.012 \\
\hline Diabetes mellitus, $n(\%)$ & $10(30.3)$ & $16(21.6)$ & 0.470 \\
\hline Hypertension, n (\%) & $23(69.7)$ & $42(56.8)$ & 0.293 \\
\hline Active smoker, $\mathrm{n}(\%)$ & $24(72.7)$ & $38(51.4)$ & 0.063 \\
\hline Onset (hour) ${ }^{\star *}$ & $6(2-24)$ & $5(2-24)$ & 0.321 \\
\hline Systolic blood pressure $(\mathrm{mmHg})^{\star *}$ & $125(80-190)$ & $130(80-200)$ & 0.787 \\
\hline Diastolic blood pressure $(\mathrm{mmHg})^{\star *}$ & $80(50-110)$ & $80(44-140)$ & 0.651 \\
\hline Anterior STEMI, $\mathrm{n}(\%)$ & $21(63.6)$ & $31(41.9)$ & 0.062 \\
\hline Haemoglobin $(\mathrm{g} / \mathrm{dL})^{*}$ & $13.8 \pm 2.1$ & $14.2 \pm 1.9$ & 0.377 \\
\hline White Blood Cell $\left(10^{3} / \mu \mathrm{L}\right)^{*}$ & $14.4 \pm 4.2$ & $13.4 \pm 3.9$ & 0.238 \\
\hline Platelet $\left(10^{3} / \mu \mathrm{L}\right)^{* *}$ & $238(144-655)$ & $266.5(117-704)$ & 0.166 \\
\hline Creatinine $(\mathrm{mg} / \mathrm{dL})^{*}$ & $1.20 \pm 0.27$ & $1.16 \pm 0.31$ & 0.527 \\
\hline Blood Glucose $(\mathrm{g} / \mathrm{dL})^{* *}$ & $168(102-521)$ & $141(86-566)$ & 0.018 \\
\hline $\mathrm{GOT}(\mathrm{IU} / \mathrm{L})^{* *}$ & $48(12-263)$ & $44(14-497)$ & 0.522 \\
\hline Creatine kinase $(\mathrm{IU} / \mathrm{mL})^{* *}$ & $1564(39-5884)$ & $464(40-7404)$ & 0.010 \\
\hline $\begin{array}{l}\text { Creatin kinase-MB }(\mathrm{IU} / \mathrm{mL})^{* *} \\
\text { Troponin I }(\mathrm{ng} / \mathrm{mL})^{* \star}\end{array}$ & $\begin{array}{c}160(25-975) \\
7.30(0.03-44)\end{array}$ & $\begin{array}{l}68.5(14-652) \\
0.49(0.01-30)\end{array}$ & $\begin{array}{l}0.004 \\
<0.001\end{array}$ \\
\hline Reperfusion method, $\mathrm{n}(\%)$ & & & 0.120 \\
\hline Primary $\mathrm{PCl}$ & $19(57.6)$ & $29(39.2)$ & \\
\hline Fibrinolysis & $14(42.4)$ & $45(60.8)$ & \\
\hline Heparin, n (\%) & $32(97.0)$ & 71 (95.9) & 0.637 \\
\hline ACEi/ARB, n (\%) & $32(97.0)$ & $66(89.2)$ & 0.170 \\
\hline Beta blocker, n (\%) & $28(84.8)$ & 67 (90.5) & 0.290 \\
\hline $\mathrm{CCB}, \mathrm{n}(\%)$ & $3(9.1)$ & $15(20.3)$ & 0.251 \\
\hline sST2 $(\mathrm{pg} / \mathrm{mL})^{*}$ & $737.03 \pm 130.67$ & $755.09 \pm 117.33$ & 0.479 \\
\hline
\end{tabular}

MACE: major advance cardiovascular event, STEMI: ST-elevation myocardial infarction, GOT: glutamic oxaloacetate transaminase, PCl: percutaneous coronary intervention, ACEi: angiotensin converting enzyme inhibitor, ARB: angiotensin receptor blocker. CCB: calcium channel blocker.

${ }^{*}$ normal data distribution, presented as mean and standart deviation, analysed with unpaired T-test

**abnormal data distribution, presented as median (minimum-maximum), analysed with Mann-Whitney test. 
Table 3. Comparison of baseline characteristics based on mortality within 90 days in STEMI patients with reperfusion

\begin{tabular}{|c|c|c|c|}
\hline Characteristic & $\begin{array}{c}\text { Mortality }(+) \\
(n=10)\end{array}$ & $\begin{array}{c}\text { Mortality }(-) \\
(\mathrm{n}=97)\end{array}$ & $\mathrm{p}$ value \\
\hline Sex, $n(\%)$ & & & 0.406 \\
\hline Male & $9(90)$ & $78(80.4)$ & \\
\hline Female & $1(10)$ & $19(19.6)$ & \\
\hline Age (year) ${ }^{*}$ & $62.8 \pm 9.2$ & $56.5 \pm 8.7$ & 0.032 \\
\hline Diabetes mellitus, $\mathrm{n}(\%)$ & $2(20)$ & $24(24.7)$ & 0.544 \\
\hline Hypertension, n (\%) & $6(60)$ & $59(60.8)$ & 0.606 \\
\hline Active smoker, n (\%) & $6(60)$ & $56(57.7)$ & 0.584 \\
\hline Onset (hour)* & $11.8 \pm 9.2$ & $7.1 \pm 5.5$ & 0.018 \\
\hline Systolic blood pressure $(\mathrm{mmHg})^{*}$ & $123.3 \pm 24.5$ & $132.7 \pm 24.8$ & 0.337 \\
\hline $\begin{array}{l}\text { Diastolic blood pressure }(\mathrm{mmHg})^{* *} \\
\text { Anterior STEMI, } \mathrm{n}(\%)\end{array}$ & $\begin{array}{l}80(50-90) \\
5(50)\end{array}$ & $\begin{array}{c}80(44-140) \\
47(48.5)\end{array}$ & $\begin{array}{l}0.824 \\
0.593\end{array}$ \\
\hline Haemoglobin $(\mathrm{g} / \mathrm{dL})^{*}$ & $13.2 \pm 2.2$ & $14.1 \pm 1.9$ & 0.145 \\
\hline White blood cell $\left(10^{3} / \mu \mathrm{L}\right)^{*}$ & $15.7 \pm 4.8$ & $13.5 \pm 3.9$ & 0.106 \\
\hline Platelet $\left(10^{3} / \mu \mathrm{L}\right)^{*}$ & $264.1 \pm 149.1$ & $270.3 \pm 86.9$ & 0.843 \\
\hline Creatinine $(\mathrm{mg} / \mathrm{dL})^{*}$ & $1.3 \pm 0.25$ & $1.2 \pm 0.30$ & 0.138 \\
\hline Blood Glukose (g/dL)* & $235.9 \pm 150.3$ & $189.8 \pm 100.4$ & 0.192 \\
\hline GOT $(I U / L)^{* *}$ & $85.3 \pm 88.7$ & $81.88 \pm 86.2$ & 0.906 \\
\hline Creatine kinase $(\mathrm{IU} / \mathrm{mL})^{*}$ & $566(39-5113)$ & $861(40-7404)$ & 0.753 \\
\hline Creatine kinase-MB $(\mathrm{IU} / \mathrm{mL})^{\star *}$ & $69(26-509)$ & $90(14-975)$ & 0.872 \\
\hline Troponin I $(\mathrm{ng} / \mathrm{mL})^{* *}$ & $2.92(0.03-30)$ & $1.89(0.01-44)$ & 0.322 \\
\hline Reperfusion method, n (\%) & & & 0.089 \\
\hline Primary $\mathrm{PCl}$ & $7(70)$ & $41(42.3)$ & \\
\hline Fibrinolysis & $3(30)$ & $56(57.7)$ & \\
\hline Heparin, n (\%) & $10(100)$ & 93 (95.9) & 0.671 \\
\hline ACEi/ARB, n (\%) & $9(90)$ & $89(91.8)$ & 0.601 \\
\hline Beta blocker, n (\%) & $7(70)$ & $88(90.7)$ & 0.083 \\
\hline CCB, n (\%) & $1(10)$ & $17(17.5)$ & 0.470 \\
\hline sST2 $(p g / m L)^{*}$ & $726.1 \pm 167.1$ & $751.9 \pm 116.4$ & 0.523 \\
\hline
\end{tabular}

STEMI: ST-elevation myocardial infarction, GOT: glutamic oxaloacetate transaminase, PCl: percutaneous coronary intervention, ACEi: angiotensin converting enzyme inhibitor, ARB: angiotensin receptor blocker. CCB: calcium channel blocker.

*normal data distribution, presented as mean and standart deviation, analysed with unpaired T-test

**abnormal data distribution, presented as median (minimum-maximum), analysed with Mann-Whitney test. 
Table 4. Comparison of baseline characteristics based on the incidence of heart failure in 90 days in STEMI patients with reperfusion

\begin{tabular}{|c|c|c|c|}
\hline Characteristic & $\begin{array}{l}\text { Heart Failure }(+) \\
\quad(n=23)\end{array}$ & $\begin{array}{l}\text { Heart Failure }(-) \\
\quad(\mathrm{n}=84)\end{array}$ & $p$ value \\
\hline Sex, n (\%) & & & 0.137 \\
\hline Male & $21(91.3)$ & $66(78.6)$ & \\
\hline Female & $2(8.7)$ & $18(21.4)$ & \\
\hline Age (year)* & $59.2 \pm 9.4$ & $56.5 \pm 8.7$ & 0.204 \\
\hline Diabetes mellitus, $n(\%)$ & $8(34.8)$ & $18(21.4)$ & 0.294 \\
\hline Hypertension, n (\%) & $17(73.9)$ & $48(57.1)$ & 0.223 \\
\hline Active smoker, n (\%) & $18(78.3)$ & $44(52.4)$ & 0.047 \\
\hline Onset (hour) ${ }^{* *}$ & $5(2-24)$ & $5(2-24)$ & 0.725 \\
\hline Systolic blood pressure $(\mathrm{mmHg})^{*}$ & $134 \pm 24.2$ & $131 \pm 25.1$ & 0.635 \\
\hline Diastolic blood pressure $(\mathrm{mmHg})^{\star *}$ & $82(60-110)$ & $80(44-140)$ & 0.505 \\
\hline Anterior STEMI, n (\%) & $16(69.6)$ & $36(42.9)$ & 0.042 \\
\hline Haemoglobin $(\mathrm{g} / \mathrm{dL})^{*}$ & $14.1 \pm 2.0$ & $14.1 \pm 1.9$ & 0.972 \\
\hline White blood cell $\left(10^{3} / \mu \mathrm{L}\right)^{*}$ & $13.8 \pm 3.8$ & $13.7 \pm 4.0$ & 0.854 \\
\hline Platelet $\left(10^{3} / \mu \mathrm{L}\right)^{*}$ & $254 \pm 65.7$ & $274 \pm 99.6$ & 0.365 \\
\hline Creatinine $(\mathrm{mg} / \mathrm{dL})^{*}$ & $1.15 \pm 0.27$ & $1.18 \pm 0.31$ & 0.737 \\
\hline Blood Glukose $(\mathrm{g} / \mathrm{dL})^{* *}$ & $167(102-367)$ & $142(86-566)$ & 0.038 \\
\hline $\mathrm{GOT}(\mathrm{IU} / \mathrm{L})^{* *}$ & $48(13-263)$ & $44(12-497)$ & 0.341 \\
\hline Creatine kinase $(\mathrm{IU} / \mathrm{mL})^{\star *}$ & $1631(180-5884)$ & $480(39-7404)$ & 0.001 \\
\hline Creatine kinase-MB $(\mathrm{IU} / \mathrm{mL})^{* *}$ & $163(25-975)$ & $68(14-652)$ & 0.002 \\
\hline Troponin I (ng/mL) $)^{*}$ & $14.07 \pm 12.58$ & $4.89 \pm 8.70$ & $<0.001$ \\
\hline Reperfusion method, $\mathrm{n}(\%)$ & & & 0.576 \\
\hline Primary $\mathrm{PCl}$ & $12(52.2)$ & $36(42.9)$ & \\
\hline Fibrinolysis & $11(47.8)$ & $48(57.1)$ & \\
\hline Heparin, n (\%) & $22(95.7)$ & $81(96.4)$ & 0.626 \\
\hline ACEi/ARB, n (\%) & $23(100)$ & $75(89.3)$ & 0.103 \\
\hline Beta blocker, n (\%) & $21(91.3)$ & $74(88.1)$ & 0.500 \\
\hline CCB, n (\%) & $2(8.7)$ & $16(19.0)$ & 0.198 \\
\hline $\mathrm{sST} 2(\mathrm{pg} / \mathrm{mL})^{*}$ & $741.79 \pm 115.49$ & $751.64 \pm 123.38$ & 0.732 \\
\hline
\end{tabular}

STEMI: ST-elevation myocardial infarction, GOT: glutamic oxaloacetate transaminase, PCl: percutaneous coronary intervention, ACEi: angiotensin converting enzyme inhibitor, ARB: angiotensin receptor blocker. CCB: calcium channel blocker.

*normal data distribution, presented as mean and standart deviation, analysed with unpaired T-test

**abnormal data distribution, presented as median (minimum-maximum), analysed with Mann-Whitney test. 
The univariate analysis of SST2 with cut-off value of $751.16 \mathrm{pg} / \mathrm{mL}$ was performed on combined MACE in STEMI patients with reperfusion therapy. The proportion of subjects experiencing MACE was slightly lower in the supramedian group (48.5\%) than infra median groups ST2 (50\%). However, the difference value was not statistically significant $(\mathrm{OR}, 0.94$; $95 \% \mathrm{Cl}, 0.41$ to $2.14 ; \mathrm{P}=1.000$ ). Similarly, when univariate analysis of SST2 levels was performed on mortality and the incidence of heart failure in 90 days, the sST2 levels did not have a significant relationship (OR, 1.02; 95\% Cl, 0.28 to $3.75 ; \mathrm{P}=0.167$ and $\mathrm{OR}, 0.92 ; 95 \% \mathrm{Cl}, 0.36$ to $2.31 ; P=1.000$, respectively).

\section{DISCUSSION}

Suppression of Tumorigenicity 2 (ST2) is a member of the family of interleukin receptor proteins (IL) -1 with two main isoforms in transmembrane or cellular form (ST2L) and soluble (SST2) that can circulate in serum. ST2 was first described in 1989. The human ST2 gene lies on the $2 q 12$ chromosome and is part of a larger group of IL-1 genes. Transcription of this gene produces four isoforms (SST2, ST2 ligand (ST2L), ST2V and ST2LV), of which two of the above have the most important role. The ST2 gene exhibits two promoters: the proximal and distal portions, which are capable of affecting the mechanism of gene transcription regulation. Each promoter has an effect on the expression of sST2 and ST2L mRNA. Genetic factors alone affect up to $40 \%$ of the variability of SST2 levels between individuals. ${ }^{11}$

The majority of heart failure cases post-myocardial infarction was due to loss of normal myocardium resulting from myocardial infarction resulting in mechanical overload of the still viable myocardium. This mechanical overload causes myocardial growth as a compensatory mechanism so that a hypertrophic myocardium can produce greater pressure.
Several pathophysiological pathways, such as angiotensin II, endothelin-1 and natriuretic factors play a role in this mechanical overload process. The contractile element of myocyte and disc of $Z$ is a mechanotransducer which conducts mechanical forces in the myocardium. ${ }^{12}$

Cardiomyocyte hypertrophy and cardiac fibrosis are common in acute MI patients. ST2 mRNA is strongly initiated in the myocytic heart cells when subjected to mechanical strain or with IL-1 $\beta$ administration, and serum SST2 levels are increased while in rat experimental animals performed ligases in their coronary arteries. ${ }^{13}$

IL-33 is a biomechanically precipitated protein in cardiac fibroblast cells in which the effect is in contrast to cardiomyocyte hypertrophy induced by angiotensin II and phenylephrine. ${ }^{14}$

This study attempted to find out the relationship between measurement of SST2 levels at admission to MACE incidence in 90 days in the form of death due to cardiovascular causes, heart failure, and heart failure readmission in STEMI patients who had undergone reperfusion therapy. In this study, the sST2 levels at admission did not have prognostic factors, either on combined MACE events, nor with mortality and the incidence of heart failure alone, within 90 days of STEMI onset.

This result differs from that of O'Donoghue et al. which stated that STEMI patients with high levels of sST2, troponin T and mieloperoksidase (MPO) have a higher risk of cardiovascular and cardiovascular death within 30 days compared with those who do not. ${ }^{15}$

These three biomarkers have different pathobiological axes: myocardial strains, myocyte necrosis, and inflammation. In the study, SST2 has a weak correlations with other strain biomarkers such as BNP, galectin-3, and troponin T. Similar phenomena are also found in NSTEMI. Experts hypothesize that ST2 does not merely play a role in myocardial strain, but also in the inflammatory, fibrosis, and myocardial 
remodeling processes. However, unlike this study in which primary $\mathrm{PCl}$ and fibrinolysis were included as reperfusion modalities, the subjects in the study were STEMI patients undergoing fibrinolysis.

In this study, the median value of SST2 is $751.16 \mathrm{pg} / \mathrm{mL}$. Minimum level obtained is $257.99 \mathrm{pg} / \mathrm{mL}$, while the maximum level is 1029 $\mathrm{pg} / \mathrm{mL}$. The 25 and $75^{\text {th }}$ percentile values are $696.38 \mathrm{pg} / \mathrm{mL}$ and $824.81 \mathrm{pg} / \mathrm{mL}$ respectively. The detection method used in this study was the ELISA sandwich technique that was sensitive in detecting the levels of a protein in the serum. The sST2 levels obtained in the study by Shimpo et al. in STEMI patients is between $85-6880 \mathrm{pg} /$ $\mathrm{mL}$ with a median value of $235 \mathrm{pg} / \mathrm{mL} .{ }^{16}$ Serum SST2 levels obtained in the study by Hartopo et al. ranged from $257.99 \mathrm{pg} / \mathrm{mL}$ to $1006.21 \mathrm{pg} / \mathrm{mL}$ with median $751.16 \mathrm{pg} / \mathrm{mL} .{ }^{9}$

In both studies, blood samples were taken at the beginning of the patient's arrival with STEMI. The level of SST2 in this study was higher than that of SST2 in the study of Sabatine et al. in STEMI patients where the median value of $80 \mathrm{pg} /$ $\mathrm{mL}$ with the 25 th and 75 th percentile values was 0 and $325 \mathrm{pg} / \mathrm{mL}$ respectively. ${ }^{17}$ In the study by Weir et al.,median of SST2 was $263.30 \mathrm{pg} / \mathrm{mL}$ with interquartile range of $139.40 \mathrm{pg} / \mathrm{mL}$ to $491.50 \mathrm{pg} /$ $\mathrm{mL} .{ }^{18} \mathrm{In}$ the study byDemyanets et al. showed median serum SST2 level of $453 \mathrm{pg} / \mathrm{mL}$ with interquartile range of $313 \mathrm{pg} / \mathrm{mL}$ to $688 \mathrm{pg} / \mathrm{mL} .^{7}$

Nevertheless, in all three studies, indirect blood samples were taken at the patient's initial presentation. Weir et al. took serum samples within 1-2 weeks after acute myocardial infarction while Sabatine et al. and Demyanets et al. took a serum sample just before the patient underwent coronary angiography (2-8 days after onset of attack). ${ }^{7,17,18}$

There is a variation in the SST2 levels obtained in this study compared with some previous studies which may be due to differences in the assay kits used and the sampling times are not the same in each study. Nevertheless, the results of this study are consistent with those studies where there is an increase in sST2 levels at the onset of STEMI. Ex-vivo data from myocardial myocyte cells undergoing biomechanical strain showed that the maximum induction of ST2 transcription occurred at 2 hour, lasted for 9 hour and began to decrease at the $15^{\text {th }}$ hour. ${ }^{17}$ Increased levels of SST2 during admission prove that at the beginning of myocardium, acute phase remodeling process has begun to occur.

Mean serum sST2 levels in healthy normal individuals were $10 \mathrm{ng} / \mathrm{mL}$ (range 5-34 ng/ $\mathrm{mL}$ ) but the results were assessed by ELISA technique using Presage ST2 assay kit. The results can not be interpolated with the ELISA R\&D system used in this study because there has never been a healthy SST2 level examination in healthy individuals with this kit before. ${ }^{19}$

Study by Hughes et al. in healthy individuals with cardiovascular risk factors showed that sST2 levels were higher in men (mean $30.4 \mathrm{ng} /$ $\mathrm{mL}$ ) than women (mean $23.8 \mathrm{ng} / \mathrm{mL}$ ). ${ }^{6}$

Similarly, study by Dieplinget et al. in healthy Austrian population, SST2 mean levels of 4-31 ng/mL were obtained in men and 2-21 $\mathrm{ng} / \mathrm{mL}$ for women. ${ }^{20} \mathrm{In}$ this study, median values of sST2 were higher in men $(764.79 \mathrm{pg} / \mathrm{mL})$ than in women $(733.74 \mathrm{pg} / \mathrm{mL})$.

Characteristic description between groups with high sST2 (>751.16 pg/mL) and low sST2 $(\leq 751.16 \mathrm{pg} / \mathrm{mL}$ ) group included demographic characteristics and clinical characteristics. Statistically, there were no significant differences between the two groups.

These results are similar to those study of Sabatine et al. whereas SST2 levels at the beginning of presentation, in contrast to NTproBNP levels, are not associated with clinical characteristics that potentially affect chronic elevation of left ventricular wall pressure such as age, sex and hypertension, previous history 
of myocardial infarction and previous history of congestive heart failure. ${ }^{17}$

In the study, the SST2 levels were strongly correlated with creatine kinase levels. Study by Demyanets et al. showed that SST2 levels were positively correlated with creatinine levels, but not with classic cardiovascular risk factors such as age, diabetes, hypertension, dyslipidemia, obesity, and smoking. ${ }^{7}$ Serum sST 2 levels are not affected by fasting conditions, body mass index, and renal function. ${ }^{20}$

In the study by Shimpo et al.,SST2 levels have a weak association with troponin I levels and are not associated with plasma BNP levels, as did study by Weir et al. ${ }^{16,18}$ This reflects that ST2 patophysiology is different from other commonly used biomarkers.

In this study, there were no significant differences from systolic and diastolic blood pressure on admission of the two SST2 groups. During observation, the hemodynamic factor at admission does not affect the occurrence of MACE.

This result differs from the study by Shimpo et al. which showed that the SST2 level on admission was associated with higher heart rate and greater systolic blood pressure despite no clinically significant hemodynamic disturbance in the study. ${ }^{16}$

All subjects in this study underwent primary $\mathrm{PCl}$ revascularization consisted of 48 subjects and fibrinolysis in 59 subjects. There is no difference between the two modalities of revascularization among subjects with high levels of ST2 and subjects with low levels of ST2. In some previous studies, levels of ST2 can be a predictor of MACE events in the form of mortality and the incidence of heart failure both short- and long-term. . $, 8,16,17$

Modality of reperfusion therapy in the study were fibrinolysis, in contrast to the population in this study where primary $\mathrm{PCl}$ was included as one of the modality of reperfusion therapy.
Reperfusion therapy with primary $\mathrm{PCl}$ is superior because it can restore coronary flow, reduce infarct size, increase fraction ejection and improve outcomes better than fibrinolysis. ${ }^{4,8}$ Authors hypothesized that patients who received primary $\mathrm{PCl}$ were having fewer cell damage progression which affected the incidence of MACE later in life. In this study, primary PCI was not a factor that independently affected the incidence of mortality and heart failure within 90 days.

The study by Weir et al. showed that serum sST2 levels did not differ significantly between anterior/anterolateral, inferior/inferiorosterior and lateral location. ${ }^{18}$

In this study, there was no significant difference in the type of infarct location in the two groups of SST2 levels but anteriorSTEMIlocation increased the risk of MACE by 2.43 times ( $p=$ 0.012 ). When associated with the incidence of heart failure within 90 days, anterior STEMI increased the risk of heart failure by $3.05(p=0.020)$. In the anterior STEMI, the strain experienced by the left ventricle is greater than that of the other STEMI sites. Study conducted by Shimpo et al. showed significantly higher anterior STEMI proportions in subjects with SST2 levels above the third quartile. ${ }^{16}$ In this study, there was no significant difference in proportion between groups with high SST2 levels and with low SST2 levels.

Treatment of patient in this study was administered in accordance with hospital guideline standards. Aspirin, clopidogrel, and heparin are given as indicated. Other drugs such as ACEi or ARB and beta blockers are given if there is no contraindication. Statin therapy is routinely administered to all patients. There was no significant difference in drug management in the high SST2 group and low SST2. At 90-day observations, the drugs were not associated with the risk of MACE, mortality and heart failure. In a study by Weir et al. in patients with high SST2 levels, the administration of eplerenone therapy 
(an aldosterone antagonist) is said to have been shown to decrease the progression of ventricular remodeling after STEMI. ${ }^{18}$

In this study, no subjects received eplerenone therapy or other aldosterone antagonistic drugs during the observation period.

\section{LIMITATIONS}

This study use retrospective design so recall bias may happens and data on medical record depends on the consideration of the clinician handling the case at that time. The total number of subjects in this study does not meet the minimal number of samples required and also the proportion of subjects in the group with MACE in this study (33 subjects) was also inadequate for the minimal proportion required (136 subjects) to achieve a research strength of $20 \%$.

This study conclude that in STEMI patients who had undergone reperfusion with high serum sST2 levels at admission, the risk of MACE for 90-days after STEMI (either mortality or the incidence of heart failure alone or both combined) was not higher than in low serum SST2 level.

\section{ACKNOWLEDGEMENT}

Authors are grateful to Mr. Farid Abdulah from Department of Clinical Pathology Faculty of Medicine Universitas Gadjah Mada for his assistance on SST2 measurement.

\section{FUNDING}

The grant of the research was from Dana Masyarakat Faculty of Medicine Universitas Gadjah Mada Fiscal Year 2016 to A.B.H (Principal Investigator).

\section{REFERENCES}

1. Krumholz H.M., Merrill A.R., Schone E.M., Schreiner G.C., Bradley E.H., Wang Y., et al. 2009. Patterns of hospital performance in acute myocardial infarction and heart failure 30-day mortality and readmission. Circ Cardiovasc Qual Outcomes, 2:407-413.

2. Jernberg T., Johanson P., Held C., Svennblad B., Lindback J., Wallentin L. 2011. Association between adoption of evidencebased treatment and survival for patients with ST-Elevation myocardial infarction. JAMA, 305(16):1677-1684.

3. O'Gara P.T., Kushner F.G., Ascheim D.D., Casey D.E., Chung M.K., Lemos J.A., et al. 2013. 2013 ACCF / AHA Guideline for the management of ST-Elevation myocardial infarction. J Am Coll Cardiol, 61(4):e78-140.

4. Steg P.G., James S.K., Badano L.P., Borger M.A., Blomstorm-Lundqvist C., DiMario C., et al. 2012. ESC Guidelines for the management of acute myocardial infarction in patients presenting with STsegment elevation The Task Force on the management of ST-segment elevation acute myocardial infarction of the European Society of Cardiology. Eur Heart J, 33:2569-2619.

5. Minicucci M.F., Azevedo P.S., Polegato B.F., Paiva S.A.R., Zornoff L.A.M. 2011. Heart failure after myocardial infarction : clinical implications and treatment. Clin Cardiol. 34(7):410-414.

6. Hughes M.F., Appelbaum S., Havulinna A.S., Jagodzinski A., Zeller T., Kee F., et al. 2014. ST2 may not be a useful predictor for incident cardiovascular events, heart failure and mortality. Heart, 100(21):1715-1721

7. Demyanets S., Speidl W.S., Tentzeris I., Jarai R., Katsaros K.M., Farhan S., et al. 2014. Soluble ST2 and interleukin-33 levels in coronary artery disease: relation to disease activity and adverse outcome. PLoS One, 21;9(4):e95055

8. Dhillon O.S., Narayan H.K., Khan S.Q., Kelly D., Quinn P.A., Squire I.B., et al. 2013. Pre-discharge risk stratification in unselected STEMI: Is there a role for ST2 or 
its natural ligand IL-33 when compared with contemporary risk markers? Int J Cardiol, 167(5):2182-2188

9. Hartopo A.B., Setianto B.Y., Taufiq N. 2016. [Pengaruh Kadar Soluble ST2 serum terhadap kejadian kardiovaskular mayor selama perawatan infark miokard akut dengan elevasi segmen ST]. Thesis. Yogyakarta: Universitas Gadjah Mada.

10. Li H., Tago K., lo K., Kuroiwa K., Arai T., Iwahana H., et al. 2000. The cloning and nucleotide sequence of human ST2L cDNA. Genomics,67:284-290.

11. Pascual-Figal D.A., Januzzi J.L. 2015. The biology of ST2: The International ST2 Consensus Panel. Am J Cardiol, 2;115(7 Suppl):3B-7B.

12. Huang H., Kamm R.D., Lee R.T. 2004. Cell mechanics and mechanotransduction : pathways, probes, and physiology. Am J Physiol Cell Physiol, 287:1-11.

13. Weinberg E.O, Shimpo M., De Keulenaer G.W., Macgillivray C., Tominaga S., Solomon S.D., et al. 2002. Receptor family member, in cardiomyocytes and myocardial infarction. Circulation, 106:2961-2967.

14. Sanada S., Hakuno D., Higgins L.J., Schreiter E.R., Mckenzie A.N.J, Lee R.T. 2007. IL-33 and ST2 comprise a critical biomechanically induced and cardioprotective signaling system. J Clin Invest, 117(6):1538-1549.

15. O'Donoghue M.L., Morrow D.A., Cannon C.P., Jarolim P., Desai N.R., Sherwood M.W., et al. 2016. Multimarker risk stratification in patients with acute myocardial infarction. $\mathrm{J}$ Am Hear Assoc, 5(5).

16. Shimpo M., Morrow D.A., Weinberg E.O., Sabatine M.S., Murphy S.A., Antman E.M., et al. 2004. Serum levels of the interleukin-1 receptor family member ST2 predict mortality and clinical outcome in acute myocardial infarction. Circulation, 109:2186-2190.

17. Sabatine M.S., Morrow D.A., Higgins L.J., MacGillivray C., Guo W., Bode C., et al. 2008. Complementary roles for biomarkers of biomechanical strain ST2 and N-Terminal Prohormone B-Type Natriuretic Peptide in patients with ST-elevation myocardial infarction. Circulation, 117(15):1936-1944.

18. Weir R.A.P., Miller A.M., Murphy G.E.J., Clements S., Steedman T., Connell J.M.C., et al. 2010. Serum soluble ST2. A potential novel mediator in left ventricular and infarct remodeling after acute myocardial infarction. J Am Coll Cardiol, 55(3):243-250.

19. Mueller T., Zimmermann M., Dieplinger B., Ankersmit H., Haltmayer M. 2012. Comparison of plasma concentrations of soluble ST2 measured by three different commercially available assays: the MBL ST2 assay, the Presage ST2 assay, and the R\&D ST2 assay. Clin Chim Acta, 413:1493-1494.

20. Dieplinger B., Januzzi Jr J., Steinmair M., Gabriel C., Poelz W., Haltmayer M. 2009. Analytical and clinical evaluation of a novel highsensitivity assay for measurement of soluble ST2 in human plasma - The Presage ${ }^{\text {TM }}$ ST2 assay. Clin Chim Acta. 409:33-40. 